\title{
Intimate relationship and its significance for eudaimonic well-being in young adults
}

\section{BACKGROUND}

Previous studies indicate that being in a relationship has a beneficial effect on the physical and mental health and also significantly affects the quality of life. One of the essential elements of the relationship is intimacy, which includes sharing experiences, support and mutual understanding, as well as respect and care for the good of the partner. Being in a relationship, the nature of this relationship (marriage vs. informal relationship) as well as the level of intimacy and the assessment of the quality of the relationship may be in relation to the personal sense of well-being. In this research we intended to estimate the significance of these variables for the sense of wellbeing and analyze which of these variables have the same meaning for the sense of well-being of young women and men.

\section{PARTICIPANTS AND PROCEDURE}

The sample consisted of 431 people (217 women and 214 men) aged 23 to 37 years (46\% of the study group were people in relationships, and $54 \%$ were single).

\section{RESULTS}

The conducted research confirmed the relationship between the sense of eudaimonic well-being and having a partner, as well as the relationship between sense of intimacy with the partner and the assessment of the quality of the relationship, indicating some differences in this respect between women and men.

\section{CONCLUSIONS}

It seems that an important issue, worth investigating in our research, concerns the reasons why individuals live a single life (voluntary and involuntary singles), and whether or not they are satisfied with this kind of life. Just as in the case of relationships it is not only the fact of being in a relationship that makes a difference but the level of satisfaction with the relationship as well, also in the case of singles satisfaction (or dissatisfaction) with living alone may prove to be significant.

KEY WORDS

well-being; marriage; cohabitation; single; young adults

ORganization - 1: Institute of Psychology, Jagiellonian University, Krakow, Poland · 2: Institute of Psychology,

Pedagogical University of Krakow, Krakow, Poland · 3: Institute of Psychology, University of Opole, Opole, Poland aUthors' Contributions - A: Study design - B: Data collection - C: Statistical analysis - D: Data interpretation .

E: Manuscript preparation · F: Literature search · G: Funds collection

Corresponding Author - Prof. Alicja M. Kalus, Institute of Psychology, University of Opole, 1 Staszica Square, 45-052 Opole, Poland, e-mail: alicja.uni@gmail.com

to Cite this ARticle - Czyżowska, D., Gurba, E., Czyżowska, N., \& Kalus, A. M. (2020). Intimate relationship and its significance for eudaimonic well-being in young adults. Health Psychology Report, 8(2), 155-166. https://doi. org/10.5114/hpr.2020.93768

RECEIVED 11.11.2019 • REVIEWED 27.02.2020 • ACCEPTED 03.03.2020 • PUBLISHED 17.03.2020 


\section{BACKGROUND}

Havighurst (1981) believes that, for the majority of young adults, a significant determinant of the sense of happiness and satisfaction with life is a successful and happy marriage as well as satisfying relations with the spouse, which are more important than the performance of tasks in other life domains, such as work, hobbies, activity for the community, or relations with friends. The importance of marriage to the contemporary respondents is pointed out in the document published by the United Nations (as cited by Myers, 2008), which reveals that more than nine out of ten people name marriage as one of the most important relationships. When asked about the most important values in life, Polish respondents named "successful marriage" second, directly after health (Czapiński \& Panek, 2004, 2007). Rucker (1993) recognizes intimate bonds as a significant factor behind a stable sense of well-being in the course of human life, and studies confirm that individuals who have a spouse or a partner are happier than singles (Argyle, 2004; Soons \& Liefbroer, 2008; Trzebińska, 2008).

Numerous studies show that close relationships not only influence our well-being, making us more satisfied or happier, but are also significant for our health (Argyle, 2004; Myers, 2008; Trzebińska, 2008; Janicka, 2012; Vanassche, Swicegood, \& Matthijs, 2013; Bucher, Neubauer, Voss, \& Oetzbach, 2019). Studies have revealed the significance of having a partner for physical and mental health (Cohen, 1988; Nelson, 1988; Coombs, 1991; Hughes \& Gove, 1981; Masterkaasa, 1992; Mendes de Leon, Apples, Otten, \& Schouten, 1992; Holt-Lunstad, Birmingham, \& Jones, 2008; Maselko, Bates, Avendano, \& Glymour, 2009; Adamczyk \& Segrin, 2015; Braithwaite \& HoltLunstad, 2017). As research results show, relationships with other people are of greater significance for wellbeing than economic status and financial resources (Diener \& Oishi, 2000). Polish studies reveal that, out of many demographic variables (e.g., education, number of children, place of residence, occupation, bonds with relatives), marital status is the best predictor of psychological well-being measured by the joy of life, the desire to live, and the quality of current life (Czapiński, 1994). Studies in which various types of relationships were examined revealed that married people were the happiest of all the categories of individuals having a partner (Argyle, 2004; Lee \& Uno, 2012).

Cutler (1979) points out that in different phases of life a person may derive satisfaction or experience worries and problems in different life domains. Because the main developmental task at the threshold of adult life is preparation for marriage, developing close intimate relationships, and building a marital relationship (Havighurst, 1981; Erikson, 1997, 2004; Arnett, 2006), it is reasonable to expect that intimate relationships and the experiences associated with them will be particularly significant for people in their early adulthood (Rauer, Pettit, Lansford, Bates, \& Dodge, 2013), contributing to their sense of happiness. This is confirmed by the results of studies in which young adults living in intimate romantic relationships proved to be happier than single individuals (Katz \& Beach, 1997; Kurdek, 1991; Soons \& Liefbroer, 2008; Adamczyk \& Segrin, 2015).

Some researchers draw attention to the gender differences in benefits derived from marriage (Johnson \& Lebow, 2000). Bernard (1972) claims that marriage is "more beneficial" for men than it is for women. Married men are physically and mentally healthier as well as more satisfied with life than single ones. Also Myers (1999) is of the opinion that it is men rather than women who gain more by getting married. This relationship is not found in the case of women, for whom the quality of marriage rather than simply being married is associated with the experience of happiness (Gove, 1972; Czapiński, 2008). It has been found that the relationship between marital satisfaction and general psychological well-being is much stronger in women than in men (Baruch \& Burnett, 1986; Proulx, Helms, \& Buehler, 2007).

\section{THE PHENOMENON OF SINGLIZATION IN CONTEMPORARY SOCIETY}

Although marriage and family are high in the hierarchy of values cherished by adolescents and young adults in Poland as well as in other countries (Slany, 2001; Czapiński \& Panek, 2004; DePaulo \& Morris, 2005; Duch-Krzystoszek \& Titkow, 2006), and although the majority of young people make entering the state of matrimony part of their life plans (Thornton \& Young-DeMarco, 2001; Kefalas, Furstenberg, Carr, \& Napolitano, 2011), there is a systematic increase in the number of people choosing forms of life alternative to marriage and family - a single person living alone (33.9\%) was the most common household type in the European Union in 2018 (Eurostat, 2019). Contemporary young people often point out that career and personal development opportunities are greater when one has not made stable marital and family commitments (Pillsworth \& Haselton, 2005; Żurek, 2008; Czernecka, 2011).

Consequently, in the context of debates concerning the significance of being in a close intimate relationship for the sense of happiness and well-being in individuals in emerging and early adulthood, it is worth reflecting on the phenomenon of singlehood, which is becoming increasingly widespread nowadays. If, as the cited studies show, being in a stable intimate relationship is so significant for a person's quality of life and sense of happiness, particularly at the threshold of adulthood and in early adulthood, then the following question can be asked: how do 
well-being and satisfaction with life develop in people who do not build such relationships and remain single? Do these individuals manifest a lower level of well-being, or are they less happy?

Given that the ability to find a partner and build a stable intimate relationship is often treated as a criterion of becoming an adult and a criterion of development in early adulthood (Havighurst, 1953; Erikson, 2004; Arnett, 2000; Seiffge-Krenke, 2003), one may wonder if taking on this task and satisfaction with its achievement can be of any significance for a person's sense of happiness and well-being. Based on the results of the studies conducted to date, it can be expected that individuals living in intimate relationships will feel happier and rate their well-being higher than singles. Nowadays, however, the self-evident nature of this association is challenged by the increasing "singlization of society" and by the belief, more and more widespread among young people, that the single lifestyle is more conducive to their self-realization. Therefore, if we assume that both groups of young adults have chosen the path which suits them the most and which gives them a chance to develop and to achieve full satisfaction in life, the thesis postulating the lack of differences between singles and people in relationships in terms of happiness and well-being is also justified.

The fact that the sample was composed of individuals in their early adulthood - a period marked, among other things, by the postponement of tasks involved in adulthood - makes it possible to consider the issue of whether there will be differences in psychological well-being between those who have already taken on the task of building a stable relationship and those who postpone the achievement of this task or decide to live a single life.

What we understand by psychological well-being is the cognitive and emotional evaluation of life performed by the person himself or herself. This evaluation comprises both judgments concerning satisfaction and the sense of fulfillment as well as emotional responses to various events (Diener, Oishi, \& Lucas, 2003). In research on well-being it is possible to distinguish two approaches, rooted in different philosophical traditions and based on different theoretical assumptions: hedonic and eudaimonic (Trzebińska, 2008; McDowell, 2009). In the hedonic approach, emphasis is placed on happiness and on the experience of pleasure (Diener \& Lucas, 1999; Kahneman, Diener, \& Schwartz, 1999), and well-being is understood as the person's subjective evaluation of life (Diener, Lucas, \& Oishi, 2002). The components of well-being in this approach are: (1) a high level of satisfaction with life, (2) a high level of positive emotions, and (3) a low level of negative emotions (Diener, Scollon, \& Lucas, 2004). In the eudaimonic approach, which is a subject of our interest, well-being is considered in terms of the realization and enrichment of personal potential. It is possible to achieve happiness by striving to discover important aspects of life and to develop positive character traits, as well as by living in accordance with one's values (Ryff, 1989; Ryff \& Singer, 2008). In the presented research it was decided to analyze whether undertaking the task of finding a partner and creating a lasting relationship is related to the dimensions of eudaimonic psychological wellbeing. Therefore, we were interested not so much in the sense of satisfaction or pleasure, which is characteristic of hedonistic well-being, but in achieving a higher level of integration, a sense of understanding ourselves and the world, independence, agency, ability to realize our potential, as well as setting and achieving life goals. Recent research results indicate the relationship between being in a relationship and a sense of well-being. However, it is worth noting that these studies mainly took into account life satisfaction (and therefore well-being in the hedonistic sense) and mental health (Adamczyk, 2019; Apostolou, Matogian, Koskeridou, Shialos, \& Georgiadou, 2019; Bucher et al., 2019).

\section{RESEARCH AIMS}

Taking into account the previous findings on the significance of being in an intimate relationship for the individual's well-being, we decided to investigate: (1) whether there is an association between having or not having a partner and eudaimonic well-being, (2) whether the type of relationship (marriage vs. nonmarital relationship), the level of intimacy between the partners, and perceived relationship quality are significant for the subjective sense of eudaimonic well-being, and (3) whether this association is present in both young women and young men. We assumed that what could be significant for eudaimonic well-being was not so much the very fact of being in a relationship as the type and quality of this relationship (recently there has been an increase in the number of non-formalized relationships, and there are reasons to believe that they differ from marriages; cf. Janicka, 2015), and that the significance of these variables could be slightly different in the case of women than in the case of men. In this context, we decided to include the perceived level of intimacy in our study, since earlier analyses had shown that the intimacy experienced in a relationship was significant for its perceived quality (Czyżowska \& Gurba, 2016).

We formulated the following hypotheses:

$\mathrm{H} 1$. There are differences in the level of eudaimonic well-being between individuals living in relationships and singles.

H1a. Individuals living in relationships have higher eudaimonic well-being than singles. This pattern is found both in the case of women and in the case of men.
Intimate relationship and psychological well-being in young adults 
H1b. Married women have higher well-being than women in nonmarital relationships.

$\mathrm{H} 1 \mathrm{c}$. In the case of men, the type of relationship is of no significance for well-being.

H2. There is an association between the level of intimacy with the partner and eudaimonic well-being. This association is stronger in the case of women than in the case of men.

H3. There is an association between perceived relationship quality and eudaimonic well-being. In the case of women this association is stronger than in the case of men.

Czyżowska,

Ewa Gurba,

Natalia

Czyżowska,

Alicja M. Kalus being: Autonomy, Environmental Mastery, Personal Growth, Positive Relations with Others, Purpose in Life, and Self-Acceptance (Ryff, 1989). The questionnaire is a self-report instrument, consisting of 84 items rated on a scale from 1 (strongly disagree) to 6 (strongly agree). Carol Ryff, the author of the concept of psychological well-being, defines it in terms of several dimensions characterizing a person's activity and attitude towards the environment. These are: (1) SelfAcceptance, (2) Purpose in Life, (3) Personal Growth, (4) Positive Relations with Others, (5) Environmental Mastery, and (6) Autonomy. Cronbach's $\alpha$ reliability coefficient for subsequent subscales of the Polish version of the Ryff Scales of Psychological Well-Being was respectively: .85 for Self-Acceptance, .84 for Purpose in Life, .78 for Personal Growth, .85 for Positive Relation with Others, .79 for Environmental Mastery and .79 for Autonomy (Karaś \& Cieciuch, 2017).

Miller Social Intimacy Scale. In the present study we also used the Polish translation of the Miller Social Intimacy Scale (MSIS) by R. Miller and H. Lefcourt, measuring the level of intimacy. The scale consists of 17 items, which the respondent rates on a scale from 1 to 10 . They concern both affective and cognitive aspects of intimacy. In the case of six items, the respondent is supposed to indicate the frequency of certain feelings towards the partner (from very rarely to almost always), whereas in the case of the remaining 11 items the task is to specify their intensity (from not at all to very much). The score is computed as the sum of the respondent's answers. The higher the score, the higher the level of intimacy. Cronbach's $\alpha$ coefficient in the research conducted by the authors of the method ranged from .86 to .91 (Miller \& Lefcourt, 1982). The test-retest reliability of the MSIS was $r=.84$ for the sample tested at an interval of one month, and $r=.91$ for the sample tested at an interval of two months (Miller \& Lefcourt, 1982). In the research presented in this article, Cronbach's $\alpha$ coefficient was .96.

Current Romantic Relationship Index. To measure perceived relationship quality, we used a Polish translation of the Current Romantic Relationship Index by Mark Regnerus (2012). The measure consists of six items concerning the way a person perceives his or her relationship. Each item is rated on a 5-point scale, from 1 (strongly disagree) to 5 (strongly agree). Cronbach's $\alpha$ coefficient in the study by Regnerus (2012) was $\alpha=.96$, and in our research it was $\alpha=.98$.

\section{RESULTS}

Ryff Scales of Psychological Well-Being. To measure the level of the participants' psychological well-being, we used the Ryff Scales of Psychological Well-Being (Ryff, 1989), as adapted into Polish by J. Cieciuch. This instrument consists of six scales measuring the levels of the following dimensions of eudaimonic well-
In order to test Hypothesis 1a, postulating differences in the level of well-being between people living in relationships and those living a single life, we compared the scores on each well-being scale between respondents who had a partner and singles. 
The analyses revealed that people living in relationships had a higher level of well-being than singles on the Purpose in Life and Self-Acceptance scales (Table 1).

Separate analyses for women and men revealed no differences between single women and women in relationships. Men, by contrast, did differ in terms of purpose in life. Men in relationships scored higher on this scale than single men. Additionally, in our attempt to determine the significance of relationship for well-being, we decided to test the significance of the type of relationship, comparing the levels of wellbeing between married people and people living in nonmarital relationships. We found no differences between married men and men living in nonmarital relationships (Hypothesis 1c) as well as a difference on the Personal Growth scale between married women and women living in nonmarital relationships (Hypothesis 1b) (Table 2).

Hypothesis 2 postulated an association between the level of intimacy with the partner and the sense of well-being. Additionally, we expected that this association would be stronger in the case of women than in the case of men.

The analyses revealed a relationship between the level of intimacy with the partner and well-being (Table 3). We found weak correlations between all well-being scales and the sense of intimacy. In the case of men, we observed no association between intimacy and the Autonomy scale. There were no other significant gender differences in the relationship between the levels of intimacy and well-being.

Hypothesis 3 postulates an association between perceived relationship quality and well-being, with the additional assumption that the association between these variables is stronger in women than in men (Table 3). Based on the results, we can say that in the case of women perceived relationship quality is significant for a broader aspect of well-being than in the case of men.

In order to determine which of the examined factors are particularly significant for the sense of wellbeing, we performed a multiple stepwise regression analysis with the following variables as predictors of well-being: relationship status, intimacy, and perceived relationship quality. The analysis was performed separately for each well-being scale.

Because research reports show that gender differences can be expected in the patterns presented here, we performed separate regression analyses for the group of women and for the group of men. For the sake of clarity, we present only the statistically significant results.

The predictor of women's well-being for the Environmental Mastery (13.4\% of explained variance; $\left.R^{2}=.13, F(1,110)=16.87, p<.001, \beta=.37, p<.001\right)$, Positive Relations with Others $\left(11.4 \%, R^{2}=.12\right.$, $F(1,110)=14.20, p<.001, \beta=.34, p<.001)$, Purpose in
Life $\left(17.4 \% ; R^{2}=.17, F(1,110)=22.98, p<.001, \beta=.42\right.$, $p<.001)$, and Self-Acceptance scales $\left(13.6 \% ; R^{2}=.14\right.$, $F(1,110)=17.12, p<.001, \beta=.37, p<.001)$ was perceived relationship quality; for the Personal Growth scale $\left(9 \% ; R^{2}=.14, F(1,110)=3.33, p<.001\right)$, the predictor was the type of relationship, with a higher level of well-being found in the case of women in nonmarital relationships $(\beta=.31, p<.01)$. In the case of men, the predictor of well-being for the Environmental Mastery scale $\left(6.2 \% ; R^{2}=.14, F(1,111)=4.20, p<.001\right.$, $\beta=.25, p<.01)$ and the Personal Growth scale $(12.8 \%$; $\left.R^{2}=.14, F(1,111)=4.29, p<.001, \beta=.36, p<.01\right)$ was found to be intimacy. Intimacy $(\beta=.21, p<.01)$ and perceived relationship quality $(\beta=.24, p<.01)$ were predictors of well-being for Self-Acceptance (4.3\% and $5.7 \%$, respectively; $\left.R^{2}=.15, F(2,110)=4.37, p<.001\right)$. Intimacy $(\beta=.21, p<.01)$ and perceived relationship quality $(\beta=.29, p<.001)$ were also predictors of Purpose in Life scales $\left(4.5 \%\right.$ and $8.2 \% ; R^{2}=.18$, $F(2,110)=5.83, p<.001)$. Neither in women nor in men did the analyzed variables predict the scores on the Autonomy and Positive Relations with Others scales of Ryff's questionnaire.

\section{DISCUSSION}

The aim of the study was to determine the significance of being in an intimate relationship, the perceived quality of this relationship, and perceived intimacy with the partner for well-being in young adults. We were interested in whether the links between the investigated variables were the same in men and in women, and in whether the level of well-being was determined by the same predictors. The analyses made it possible to verify most of the hypotheses.

As expected, we found a relationship between well-being and having an intimate partner. People in relationships scored higher on the Purpose in Life and Self-Acceptance scales. It is worth noting that self-acceptance constitutes the basic component of well-being - a component that means self-respect stemming from the ability to realistically evaluate oneself and to accept one's virtues and vices. The obtained results show that people in relationships accept themselves to a greater degree and approach themselves with more respect. Perhaps being in an intimate relationship with another person and building a stable relationship with him or her is a significant source of self-respect and positive thinking about oneself as well as more adequate self-knowledge. Being loved and accepted by the partner can be conducive to thinking well of oneself. The results of the presented research show that being in an intimate relationship is also associated with higher sense of meaning in life, which means the ability to define one's purpose in life, to set oneself new tasks, and to achieve these tasks. This makes it legitimate to expect that having
Intimate relationship and psychological well-being in young adults 


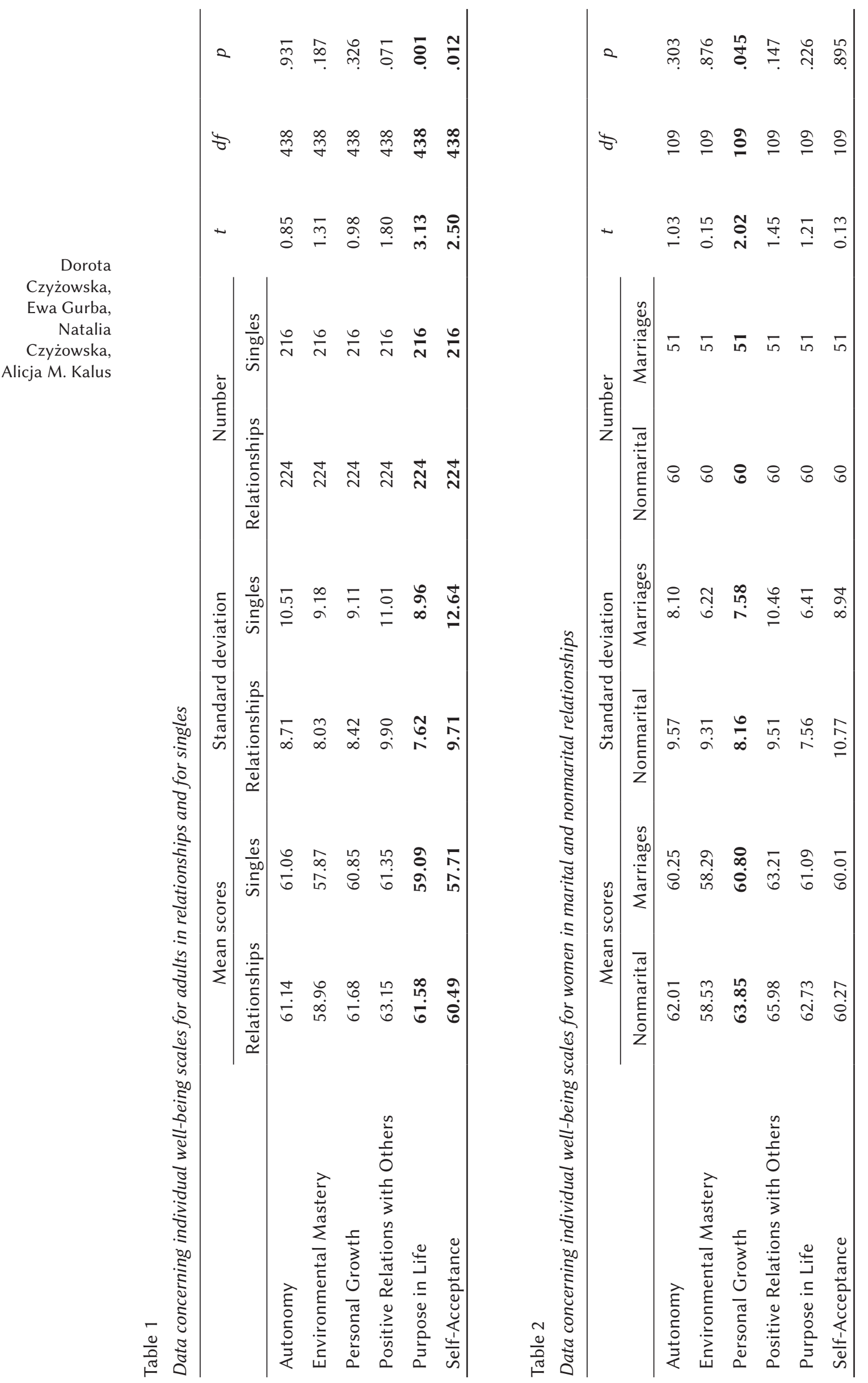




\begin{tabular}{lcccc}
\hline & \multicolumn{2}{c}{ Intimacy } & \multicolumn{2}{c}{ Perceived relationship quality } \\
\cline { 2 - 5 } & Women & Men & Women & Men \\
\hline Autonomy & $.19^{*}$ & .06 & .06 & -.14 \\
Environmental Mastery & $.20^{*}$ & $.30^{*}$ & $.29^{*}$ & .14 \\
Personal Growth & $.27^{*}$ & $.35^{*}$ & .07 & .11 \\
Positive Relations with Others & $.34^{*}$ & $.29^{*}$ & $.22^{*}$ & $.21^{*}$ \\
Purpose in Life & $.41^{*}$ & $.36^{*}$ & $.36^{*}$ & $.30^{*}$ \\
Self-Acceptance & $.40^{*}$ & $.32^{*}$ & $.24^{*}$ & -.02 \\
\hline
\end{tabular}

Note. ${ }^{*} p<.05$

a partner may be associated with a sense of security, support, and stability in life, which motivates the person to take up new challenges and set him or herself new tasks - often developed together with the partner - whose achievement gives them a sense of meaning in life. The very fact of having a partner and starting a family opens up an area of new tasks before an individual, and thus it may be conducive to building a sense of meaning in life. It cannot be excluded, however, that the fact that a person accepts him or herself - having a realistic self-image - makes it easier for that person to find a partner and make a decision to build a relationship with them. Also the ability to ask oneself questions and choose one's goal in life may be conducive to finding a partner and may foster willingness to build a stable relationship. It is worth noting that our results, pointing to the significance of being in a relationship for well-being, are consistent with the results of previous studies addressing this issue (Argyle, 2004; Myers, 2008; Trzebińska, 2008; Apostolou et al., 2019; Bucher et al., 2019; Grover \& Helliwell, 2019). The separate analyses conducted for women and for men revealed no differences between single women and women living in relationships, whereas men living in relationships scored higher on Purpose in Life. This result seems to confirm the findings of earlier studies, which showed that being in a relationship was more significant in the case of men than in the case of women, and that it was men who were usually beneficiaries of intimate relationships (Bernard, 1972; Myers, 1999). Although having a partner is associated with every aspect of well-being, it should be noted that individuals living a single life did not score higher than subjects having a partner on any of the well-being scales.

As expected, we found an association between perceived intimacy in the relationship and well-being. Intimacy was related to the sense of autonomy, environmental mastery, and personal growth. We observed small differences in this respect between women and men. In the case of women, intimacy was related to all well-being scales. In men, we found no association of intimacy with the Autonomy scale. Based on the obtained results, we can say that both in the case of women and in the case of men intimacy is an important element of well-being. This means that partners' intimacy, tenderness, and openness to each other and to each other's needs turn out to be significant to well-being both in women and in men. It is worth noting that this actually refers to all dimensions of well-being. In the case of men, intimacy is not associated only with the sense of internal independence and with the ability not to yield to external pressure.

Two of the explanatory variables analyzed here - sense of intimacy and having an intimate partner - were found to be equally strong predictors of two dimensions of well-being: Purpose in Life and SelfAcceptance.

As expected, perceived relationship quality is also associated with well-being. Higher satisfaction with the relationship is accompanied by higher levels of the following dimensions of well-being: purpose in life, relations with others, and environmental mastery; the last of these associations (between perceived relationship quality and environmental mastery) was not found in men. The subjects who evaluate their relationship more positively are more capable of finding meaning in life and constantly setting themselves new tasks; they evaluate their ability to maintain good relations with others and to experience positive emotions in the relationship as higher, and they believe they cope well with the surrounding reality. In the case of women, higher satisfaction with the relationship is also associated with self-acceptance. Positive evaluation of the relationship, the sense of intimacy with and support from the partner, and satisfaction with the relationship may be conducive to the belief that one is able to build good relationships, to experience positive emotions, and to find meaning in one's life, which in turn leads to constantly setting oneself new tasks and challenges. A good intimate relationship and a sense of being accepted by some-
Intimate relationship and psychological well-being in young adults 
one may also be conducive to thinking positively about oneself and to self-acceptance. The association between positive perceived relationship quality and self-acceptance confirms that for women relationships with other people are of special importance, and that when thinking about themselves women usually do it in the context of relations with other people. Our results are consistent with those obtained in other studies, which also revealed the significance of satisfaction with the relationship for well-being (Campbell, Converse, \& Rodgers, 1976; Czapiński, 1994; Carr, Freedman, Cornman, \& Schwarz, 2014).

Based on research results suggesting that the significance of being in a relationship for well-being may be different in women and in men, we decided to determine the predictors of well-being separately for either sex. We established that the predictors of well-being in women are perceived relationship quality (for Environmental Mastery, Positive Relations with Others, Purpose in Life, and Self-Acceptance) and the type of relationship (only for the Personal Growth scale). This result confirms the previously reported finding that what is significant for women and for their well-being is not so much the fact of being in a relationship as the quality of that relationship (Gove, 1972; Baruch \& Burnett, 1986; Czapiński, 2008). As the analyses of results have shown, women living in nonmarital relationships exhibit a greater ability than married women to discover and constantly use their potential and to develop new skills. This result can be treated as a confirmation of the fact that women often engage in marital and family life at the cost of their own development and their own desires. It should be noted, however, that the participants in the study were young women, most of whom had been married only for a short time; they were only entering the role of a wife and a mother and learning the new roles. In this period, the women may be more strongly focused on meeting the expectations associated with these roles and on looking for ways to properly perform the tasks involved than on themselves, their own needs, and their own development. This, however, does not have to mean that married life limits developmental possibilities. Perhaps in the case of women who have been married for a longer time and who have developed their own way of fulfilling the role of a wife and mother, consistent with their preferences and individual characteristics, there appears a greater awareness of their developmental potential and greater care to make use of it. In order to find out whether and to what extent married life limits women's capability of discovering and using their developmental potential, it would be necessary to examine older women (e.g., in their middle adulthood) with a longer time in marriage behind them.

What turned out to be significant for men's wellbeing was the sense of intimacy and perceived relationship quality. It is worth noting that in the case of men intimacy constitutes a predictor for four out of six well-being scales (Environmental Mastery, Personal Growth, Self-Acceptance, and Purpose in Life), whereas in the case of women intimacy did not function at all as a predictor of well-being. The obtained results make it possible to conclude that intimacy is of greater significance for well-being in young men than in young women. The sense of intimacy, showing each other feelings and tenderness, as well as spending time together, seem to influence self-respect, discovering and being guided by one's potential, the ability to cope with the surrounding reality, and the ability to set oneself life goals to a greater degree in the case of men than in the case of women, for whom satisfaction with the relationship and its positive evaluation prove to be more significant. It can therefore be concluded, even though it requires empirical investigation, that women build satisfaction with the relationship and evaluate it also based on dimensions other than intimacy.

To sum up, the factors significant for well-being considered in terms of the realization and enrichment of personal potential and in terms of striving for valuable attributes are both having a partner and the sense of intimacy as well as perceived relationship quality. The obtained results are consistent with those of previous studies, where relationship quality was also found to be a predictor of well-being and the sense of happiness (Glenn \& Weaver, 1979; Inglehart, 1990; Myers, 1993; Campbell et al., 1976; Czapiński, 1994; Margelisch, Schneewind, Violette, \& PerrigChiello, 2017). Our research has confirmed that the factors of particular significance to women are relationship quality and satisfaction with the relationship. What has proved to be significant to men is the sense of intimacy, which seems to be more important than perceived relationship quality.

Contrary to expectations, the type of relationship (marriage vs. nonmarital relationship) was not found to be significant for self-perceived well-being. This result is not consistent with those of earlier research, in which it was found that married individuals were the happiest of all people who had a partner (Argyle, 2004; Wiik, Keizer, \& Lappegård, 2012; Brown, Manning, \& Payne, 2017). Also the data showing that women were more interested in marriage than in a nonmarital relationship made it reasonable to expect that women in nonmarital relationships would have a lower level of well-being than married women. The obtained results may suggest that young people's attitudes towards marriage and nonmarital relationships are changing, and that both men and women accept and positively evaluate nonmarital relationships. Studies show that as cohabitation becomes more and more acceptable, the difference between a sense of well-being in people in formal and informal relationships can become blurred (Rijken \& Liefbroer, 2016; Blekesaune, 2018). What may also be of significance 
is the fact that we surveyed a group of young adults, most of whom had been in a relationship for a relatively short time and had no children. Some of the subjects may have treated cohabitation as a preliminary stage on the way towards marriage. The results of our study seem to be consistent with the results of research revealing that the attitude to cohabitation and its influence on well-being, particularly in women, may depend on whether or not one has children (Robins \& Regier, 1991). When discussing the significance of having a partner, perceived intimacy, and perceived relationship quality for well-being, we must not, of course, fail to mention the fact that regression analysis reveals that intimacy and relationship quality explain only a few percent or between ten and twenty percent of variance in well-being. This, undoubtedly, stems from the fact that, being a complex construct, well-being is influenced by numerous factors (such as satisfaction with professional activity or economic status). There is no doubt, however, that finding a partner as well as building a satisfying relationship based on intimacy and mutual understanding is significant for discovering important aspects of life, setting one's life goals, constantly discovering one's possibilities of development, and experiencing positive emotions. Young people's attitude to romantic relationships is changing: they more and more often postpone starting a stable relationship or decide to live a single life, and they choose non-formalized relationships instead of marriage. Still, being in a relationship does give them a sense of satisfaction, increase their sense of meaning in life, and contribute to their experience of self-respect.

It is worth emphasizing once again that although the relationship between being in a relationship and a sense of well-being has already been studied, those studies mostly related to the subjective sense of satisfaction (Adamczyk, 2019; Apostolou et al., 2019; Bucher et al., 2019). In our research, we tried to determine whether finding a partner and building a relationship, its quality and the level of intimacy experienced are important for understanding and expressing self, mental integration, updating and enriching own potential, and determining and achieving life goals.

The research reported in the present paper undoubtedly expands our knowledge about the significance of intimate relationships for young adults' well-being, though of course we are aware that we have only managed to determine the significance of selected variables and that the association between lifestyle (in a relationship or single) and well-being requires further study. It seems that an important issue, worth investigating in our research, concerns the reasons why individuals live a single life (voluntary and involuntary singles), and whether or not they are satisfied with this kind of life. Just as in the case of relationships it is not only the fact of being in a rela- tionship that makes a difference but the level of satisfaction with the relationship as well, also in the case of singles satisfaction (or dissatisfaction) with living alone may prove to be significant. Results that suggest the validity of this direction in research are already available (Lehmann et al., 2015; Adamczyk, 2017).

\section{References}

Adamczyk, K. (2017). Voluntary and involuntary singlehood and young adults' mental health: an investigation of mediating role of romantic loneliness. Current Problems in Psychology, 36, 888-904. https://doi.org/10.1007/s12144-016-9478-3

Adamczyk, K. (2019). Development and validation of a Polish-language version of the Satisfaction with Relationship Status Scale (ReSta). Current Psychology, 38, 8-20. https://doi.org/10.1007/s12144017-9585-9

Adamczyk, K., \& Segrin, C. (2015). Direct and indirect effects of young adults' relationship status on life satisfaction through loneliness and perceived social support. Psychologica Belgica, 55, 196-211. https://doi.org/10.5334/pb.bn

Apostolou, M., Matogian, I., Koskeridou, G., Shialos, M., \& Georgiadou, P. (2019). The price of singlehood: Assessing the impact of involuntary singlehood on emotions and life satisfaction. Evolutionary Psychological Science, 5, 416-425. https://doi.org/10.1007/ s40806-019-00199-9

Argyle, M. (2004). Psychologia szczęścia [Psychology of happiness]. Wrocław: Astrum.

Arnett, J. J. (2000). Emerging adulthood: a theory of development from the late teens through the twenties. American Psychologist, 55, 469-480. https://doi. org/10.1037/0003-066X.55.5.469

Arnett, J. J. (2006). The cultural psychology of emerging adulthood. Paper presented at the Biennial Meeting of Society for Research on Adolescence, San Francisco, CA.

Baruch, G. K., \& Barnett, R. (1986). Role quality, multiple role involvement, and psychological wellbeing in midlife women. Journal of Personality and Social Psychology, 51, 578-585. https://doi.org/10. 1037/0022-3514.51.3.578

Bernard, J. (1972). The future of marriage. New York: Word Publishing.

Blekesaune, M. (2018). Is cohabitation as good as marriage for people's subjective well-being? Longitudinal evidence on happiness and life satisfaction in the British household panel survey. Journal of Happiness Studies, 19, 505-520. https://doi. org/10.1007/s10902-016-9834-x

Braithwaite, S., \& Holt-Lunstad, J. (2017). Romantic relationships and mental health. Current Opinion in Psychology, 13, 120-125. https://doi.org/10.1016/j. copsyc.2016.04.001
Intimate relationship and psychological well-being in young adults 
Brown, S. L., Manning, W. D., \& Payne, K. K. (2017) Relationship quality among cohabiting versus married couples. Journal of Family Issues, 38, 1730-1753. https://doi.org/10.1177/0192513X15622236

Bucher, A., Neubauer, A. B., Voss, A., \& Oetzbach, C. (2019). Together is better: Higher committed relationships increase life satisfaction and reduce loneliness. Journal of Happiness Studies, 20, 24452469. https://doi.org/10.1007/s10902-018-0057-1

Campbell, A., Converse, P. E., \& Rodgers W. L. (1976). The quality of American life. New York: Sage.

Czyżowska,

Ewa Gurba,

Natalia

Czyżowska,

Alicja M. Kalus

Carr, D., Freedman, V. A., Cornman, J. C., \& Schwarz, N. (2014). Happy marriage, happy life? Marital quality and subjective well-being in later life. Journal of Marriage and Family, 76, 930-948. https://doi. org/10.1111/jomf.12133

Cohen, S. (1988). Psychosocial model of the role of social support in the etiology of physical disease. Health Psychology, 7, 269-297. https://doi.org/10. 1037/0278-6133.7.3.269

Coombs, R. (1991). Marital status and personal wellbeing: a literature review. Family Relations, 40, 97-102. https://doi.org/10.2307/585665

Cutler, S. J. (1979). Age variations in the dimensionality of life satisfaction. Journal of Gerontology, 34, 573-578. https://doi.org/10.1093/geronj/34.4.573

Czapiński, J. (1994). Psychologia szczęścia. Przeglad badań i zarys teorii cebulowej [Psychology of happiness. Review of research and outline of onion theory]. Warszawa: Pracownia Testów Psychologicznych PTP.

Czapiński, J. (2008). Psychologia pozytywna [Positive psychology]. Warszawa: PWN.

Czapiński, J., \& Panek, T. (2004). Diagnoza spoteczna 2003 [Social Diagnosis 2003]. Warszawa: Wydawnictwo Wyższej Szkoły Finansów i Zarządzania.

Czapiński, J., \& Panek, T. (2007). Diagnoza społeczna 2007 [Social Diagnosis 2007]. Retrieved from http:// www.diagnoza.com/pliki/raporty/Diagnoza_raport_2007.pdf

Czernecka, J. (2011). Wielkomiejscy single [Big city singles]. Warszawa: Wydawnictwo Poltext.

Czyżowska, D., \& Gurba, E. (2016). Bliskość w relacjach z rodzicami a przywiązanie i poziom intymności u młodych dorosłych [Closeness in parental relations and the later level of commitment and intimacy experienced by young adults]. Psychologia Rozwojowa, 21, 91-107. https://doi.org/10.4467 /20843879PR.16.024.6001

DePaulo, B., \& Morris, W. (2005). Singles in society and in science. Psychological Inquiry, 16, 57-83. https://doi.org/10.1207/s15327965pli162\&3_01

Diener, E., \& Lucas, R. E. (1999). Personality and subjective well-being. In D. Kahneman, E. Diener, \& N. Schwarz (Eds.), Well-being: The foundations of hedonic psychology (pp. 213-229). New York: Russell Sage.

Diener, E., Lucas R. E., \& Oishi S. (2002). Subjective well-being: The science of happiness and life satis- faction. In C. R. Snyder \& S. J. Lopez (Eds.), Handbook of positive psychology (pp. 63-73). New York: Oxford University Press.

Diener, E., \& Oishi, S. (2000). Money and happiness: Income and subjective well-being across nations. In E. Diener \& E. M. Suh (Eds.), Culture and subjective well-being (pp. 185-218). Cambridge, MA: The MIT Press.

Diener, E., Oishi, S., \& Lucas, R. E. (2003). Personality, culture, and subjective well-being: Emotional and cognitive evaluations of life. Annual Review of Psychology, 54, 403-425. https://doi.org/10.1146/ annurev.psych.54.101601.145056

Diener, E., Scollon, C. N., \& Lucas, R. E. (2004). The evolving concept of subjective well- being: The multifaceted nature of happiness. In P. T. Costa \& I. Siegler (Eds.), Advances in cell aging and gerontology (Vol. 15, pp. 187-220). Amsterdam: Elsevier.

Duch-Krzystoszek, D., \& Titkow, A. (2006). Polka i jej rodzina na tle Europy. Redystrybucja prac domowych; jej uczestnicy i konteksty [A Polish woman and her family against the backdrop of Europe. Redistribution of housework; its participants and contexts]. In H. Domański, A. Ostrowska, \& P. B. Sztabiński (Eds.), W środku Europy? Wyniki Europejskiego Sondażu Spotecznego [In the middle of Europe? Results of the European Social Survey]. Warszawa: Wydawnictwo IFiS PAN.

Erikson, E. H. (1997). Dzieciństwo i spoteczeństwo [Childhood and society]. Poznań: Dom Wydawniczy Rebis.

Erikson, E. H. (2004). Tożsamość a cykl życia [Identity and the life cycle]. Poznań: Wydawnictwo Zysk i S-ka.

Eurostat (2019). Household composition statistics. Retrieved from https://ec.europa.eu/eurostat/statistics-explained/index.php/Household_composition_statistics\#Household_size

Glenn, N. D., \& Weaver, C. N. (1979). A note on family situation and global happiness. Social Forces, 57, 960-967. https://doi.org/10.2307/2577364

Gove, W. R. (1972). The relationship between sex roles, marital status, and mental illness. Social Forces, 51, 34-44. https://doi.org/10.2307/2576129

Grover, S., \& Helliwell, J. F. (2019). How's life at home? New evidence on marriage and the set point for happiness. Journal of Happiness Studies, 20, 373390. https://doi.org/10.1007/s10902-017-9941-3

Havighurst, R. J. (1953) Human development and education. New York: Longmans and Green.

Havighurst, R. J. (1981). Developmental tasks and education. New York: Longmans and Green.

Hertel, J., Schütz, A., DePaulo, B. M., Morris, W. L., \& Stucke, T. S. (2007). She's single, so what? How are singles perceived compared with people who are married? Zeitschrift für Familienforschung, 2, 139-158.

Holt-Lunstad, J., Birmingham, W., \& Jones, B. Q. (2008). Is there something unique about marriage? 
The relative impact of marital status, relationship quality, and network social support on ambulatory blood pressure and mental health. Annals of Behavioral Medicine, 35, 239-244. https://doi.org/10.1007/ s12160-008-9018-y

Hughes, M., \& Gove, W. R. (1981). Living alone, social integration, and mental health: a longitudinal study of cohort of young adults. American Journal of Sociology, 87, 48-74. https://doi.org/10.1086/227419

Janicka, I. (2012). Poczucie dobrostanu u osób poślubionych, kohabitujących i u singli [A sense of wellbeing in married, cohabiting and single people]. In T. Rostowska \& M. Lewandowska-Walter (Eds.), Matżeństwo i rodzicielstwo a zdrowie [Marriage, parenthood and health] (pp. 26-53). Toruń: Wydawnictwo Adam Marszałek

Janicka, I. (2015). Związki kohabitacyjne [Cohabiting relationships]. In I. Janicka \& H. Liberska (Eds.), Psychologia rodziny [Family Psychology] (pp. 259284). Warszawa: PWN

Johnson, S., \& Lebow, J. (2000). The "coming of age" of couple therapy: a decade review. Journal of Marital and Family Therapy, 26, 23-38. https://doi. org/10.1111/j.1752-0606.2000.tb00273.x

Kahneman, D., Diener, E., \& Schwarz, N. (1999). Wellbeing: Foundations of hedonic psychology. New York: Russell Sage Foundation.

Karaś, D., \& Cieciuch, J. (2017). Polska adaptacja Kwestionariusza Dobrostanu (Psychological Well-Being Scales) Caroll Ryff [Polish adaptation of Carol Ryff's Psychological Well-Being Scales]. Roczniki Psychologiczne, 20, 815-835.

Katz, J., \& Beach, S. (1997). Self-verification and depressive symptoms marriage and courtship: a multiple pathway model. Journal of Marriage and Family, 59, 903-914. https://doi.org/10.2307/353791

Kefalas, M. J., Furstenberg, F. F., Carr, P. J., \& Napolitano, L. (2011). Marriage is more than being together: The meaning of marriage for young adults. Journal of Family Issue, 32, 845-875. https://doi. org/10.1177/0192513X10397277

Kurdek, L. (1991). The relations between reported well-being and divorce history availability of proximate adult, and gender. Journal of Marriage and the Family, 53, 71-78. https://doi.org/10.2307/353134

Lee, K. S., \& Uno, H. (2012). Marriage, cohabitation, and happiness: a cross-national analysis of 27 countries. Journal of Marriage and Family, 74, 953-972. https://doi.org/10.1111/j.1741-3737.2012.01001.x

Lehmann, V., Tuinman, M. A., Braeken, J., Vingerhoets, A. J. J. M., Sanderman, R., \& Hagedoorn, M. (2015). Satisfaction with relationship status: Development of a new scale and the role in predicting well-being. Journal of Happiness Studies, 16, 169184. https://doi.org/10.1007/s10902-014-9503-x

Margelisch, K., Schneewind, K. A., Violette J., \& PerrigChiello, P. (2017). Marital stability, satisfaction and well-being in old age: variability and continuity in long-term continuously married older persons. Aging \& Mental Health, 21, 389-398. https://doi.org/ 10.1080/13607863.2015.1102197

Maselko, J., Bates, L. M., Avendano, M., \& Glymour, M. M. (2009). The intersection of sex, marital status, and cardiovascular risk factors in shaping stroke incidence: Results from the Health and Retirement Study. Journal of the American Geriatrics Society, 57, 2293-2299. https://doi.org/10.1111/ j.1532-5415.2009.02555.x

Masterkaasa, A. (1992). Marriage and psychological well-being: Some evidence on selection into marriage. Journal of Marriage and Family, 54, 901-911. https://doi.org/10.2307/353171

McDowell, I. (2009). Measures of self-perceived wellbeing. Journal of Psychosomatic Research, 69, 69-79. https://doi.org/10.1016/j.jpsychores.2009.07.002

Mendes de Leon, C. F., Apples, A. W., Otten, F. W., \& Schouten, E. G. (1992). Risk of mortality and coronary heart disease by marital status in middle-aged men in the Netherlands. International Journal of Epidemiology, 21, 460-466. https://doi. org/10.1093/ije/21.3.460

Miller, P. C., \& Lefcourt, H. M. (1982). The assessment of social intimacy. Journal of Personality Assessment, 46, 514-518. https://doi.org/10.1207/s153 27752jpa4605_12

Myers, D. G. (1993). The pursuit of happiness. New York: Avon Books.

Myers, D. G. (1999). Close relationships and quality of life. In D. Kahneman, E. Diener, \& N. Schwarz (Eds.), Well-being: The foundations of hedonic psychology (pp. 374-391). New York: Russell Sage Foundation.

Myers, D. G. (2008). Bliskie związki a jakość życia [Close relationships and quality of life]. In J. Czapiński (Ed.), Psychologia pozytywna. Nauka o szczęściu, zdrowiu, sile i cnotach człowieka [Positive psychology. The science of happiness, health, strength and virtues] (pp. 204-234). Warszawa: PWN.

Nelson, N. (1988). A meta-analysis of the life-event/ health paradigm: The influence of social support. Unpublished doctoral thesis. Temple University, Philadelphia, PA.

Pillsworth, E. G., \& Haselton, M. G. (2005). The evolution of coupling. Psychological Inquiry, 16, 98-104.

Proulx, C. M., Helms, H. M., \& Buehler, C. (2007). Marital quality and personal well-being: a meta-analysis. Journal of Marriage and Family, 69, 576-593. https://doi.org/10.1111/j.1741-3737.2007.00393.x

Rauer, A. J., Pettit, G. S., Lansford, J. E., Bates J. E., \& Dodge, K. A. (2013) Romantic relationship patterns in young adulthood and their developmental antecedents. Developmental Psychology, 49, 2159-2171. https://doi.org/10.1037/a0031845

Regnerus, M. (2012). How different are the adult children of parents who have the same-sex relationships? Findings from the New Family Struc-
Intimate relationship and psychological well-being in young adults 
tures Study. Social Science Research, 41, 752-770. https://doi.org/10.1016/j.ssresearch.2012.03.009

Rijken, A. J., \& Liefbroer, A. C. (2016). Differences in family norms for men and women across Europe. Journal of Marriage and Family, 78, 1097-1113. https://doi.org/10.1111/jomf. 12310

Robins, L., \& Regier, D. (1991). Psychiatric disorders in America: The epidemiological catchment area study. New York: Free Press.

Rucker, N. (1993). Cupid's misses: Relational vicissitudes in the analyses of single woman. Psycho-

Dorota

Czyżowska,

Ewa Gurba,

Natalia

Czyżowska,

Alicja M. Kalus analytic Psychology, 10, 377-391. https://doi.org/ 10.1037/h0079468

Ryff, C. D. (1989). In the eye of the beholder: Views of psychological well-being among middle-aged and older adults. Psychology and Aging, 4, 195-210. https://doi.org/10.1037/0882-7974.4.2.195

Ryff, C. D., \& Singer, B. H. (2008). Know thyself and become what you are: a eudaimonic approach to psychological well-being. Journal of Happiness Studies, 9, 1, 13-39. https://doi.org/10.1007/s10902006-9019-0

Seiffge-Krenke, I. (2003). Testing theories of romantic development from adolescence to young adulthood: Evidence of a developmental sequence. International Journal of Behavioral Development, 27, 519531. https://doi.org/10.1080/01650250344000145

Slany, K. (2001). Małżeństwo i rodzina w zglobalizowanym świecie [Marriage and family in a globalized world]. Problemy Rodziny, 6, 3-10.

Soons, J. P. M., \& Liefbroer, A. C. (2008). Together is better? Effects of relationship status and resources on young adults' well-being. Journal of Social and Personal Relationships, 25, 603-624. https:// doi.org/10.1177/0265407508093789

Thornton, A., \& Young-DeMarco, L. (2001). Four decades of trends in attitudes toward family issues in the United States: The 1960s through the 1990s. Journal of Marriage and Family, 63, 1009-1037. https://doi.org/10.1111/j.1741-3737.2001.01009.x

Trzebińska, E. (2008). Psychologia pozytywna [Positive psychology]. Warszawa: Wydawnictwa $\mathrm{Na}$ ukowe i Profesjonalne.

Vanassche, S., Swicegood, G., \& Matthijs, K. (2013). Marriage and children as a key to happiness? Cross-national differences in the effects of marital status and children on well-being. Journal of Happiness Studies, 14, 501-524. https://doi.org/10.1007/ s10902-012-9340-8

Wiik, K. A., Keizer, R., \& Lappegård, T. (2012). Relationship quality in marital and cohabiting unions across Europe. Journal of Marriage and Family, 74, 389-398. https://doi.org/10.1111/j.1741-3737.2012.00967.x

Żurek, A. (2008). Single. Żyjąc w pojedynkę [Singles. Living alone]. Poznań: Wydawnictwo Naukowe UAM. 